\title{
Transesterification and Production of Biodiesel from Waste Cooking Oil: Effect of Operation Variables on Fuel Properties
}

\author{
Falah Fahed Banihani \\ Department of Chemical Engineering, Al-Huson University College, Al-Balqa Applied University, Al-Huson, Jordan
}

Email address:

falahfah@yahoo.com

To cite this article:

Falah Fahed Banihani. Transesterification and Production of Biodiesel from Waste Cooking Oil: Effect of Operation Variables on Fuel Properties. American Journal of Chemical Engineering. Vol. 4, No. 6, 2016, pp. 154-160. doi: 10.11648/j.ajche.20160406.13

Received: November 17, 2016; Accepted: December 1, 2016; Published: January 5, 2017

\begin{abstract}
Biodiesel is proved to be the best replacement for diesel because of its unique properties like low toxicity, no sulfur emissions, no particulate matter pollutants, significant reduction in greenhouse gas emissions and biodegradability. Several processes for biodiesel fuel production have been developed, among which transesterification using alkali catalysis gives high levels of conversion of triglycerides to their corresponding methyl esters in short reaction times. It is prepared from waste vegetable oils and animal fats by trans-esterification process. It is alkali catalyzed reaction which involves waste cooking oil, methanol, and potassium hydroxide. The study focus on the physical and chemical properties of waste cooking oil (WCO), transesterification and production of biodiesel from WCO. The operation variables used were methanol/oil molar ratio (5:19:1), catalyst concentration $(0.5-2.0 \mathrm{wt} \%)$, temperature $\left(30-70^{\circ} \mathrm{C}\right)$. The evolution of the process was followed by gas chromatography, determining the concentration of the methyl esters at different reaction times. The biodiesel was characterized by its density, viscosity, high heating value, cetane index, cloud and pour points, characteristics of distillation, flash and combustion points, saponification value, and iodine value according to ISO norms. The biodiesel with the best properties was obtained using a methanol/oil molar ratio of $6: 1$, potassium hydroxide as catalyst $(1 \%)$, and $60^{\circ} \mathrm{C}$ temperature. This biodiesel had properties very similar to those of no. 2 diesel.
\end{abstract}

Keywords: Trans-Esterification, Biodiesel, Alternative Fuel, Fuel Properties, Waste Oil

\section{Introduction}

Increasing concerns regarding environmental impacts, the soaring price of petroleum products together with the depletion of fossil fuels have prompted considerable research to identify alternative fuel sources. Biofuel has recently attracted huge attention in different countries all over the world because of its renewability, better gas emissions and its biodegradability. It is estimated that biodiesel/bio-ethanol could replace approximately $10 \%$ of diesel fuel consumption within Europe and 5\% of Southeast Asia's total fuel demand [1]. The alternatives to diesel fuel must be technically feasible, economically competitive, environmentally acceptable, and readily available. Many of these requisites are satisfied by vegetable oils or, in general, by triglycerides. Indeed, vegetable oils are widely available from a variety of sources, and they are renewable. Also, these fuels are easily biodegradable, they have practically null sulfur content, and their transport and storage offer no problems. Consequently, these products can be considered viable alternatives for diesel fuel [2, 3]. Their main drawback is price, which is higher than for oil derived diesels. In consequence, their use must be accompanied by a policy oriented toward their total tax exemption. However, WCO is used as a diesel fuel substitute. Large quantities of WCO are available throughout the world. Estimates of the amount of WCO in the US range from 4.5 billion to 11.3 billion liters a year [4]. WCO is used as additive oil for fodder preparation and in the manufacture of soap. In some other countries, the oil from the better restaurants then goes to poorer ones, or perhaps to individuals for food preparation. In few restaurants, the vegetable oil after the 
first use is passed through an oil recycler and then reused for cooking. After the second use, the oil is collected in a common slump and sent to microbiological laboratory for the manufacture of soap. In a few countries, the use of $\mathrm{WCO}$ in the production of animal feeding is prohibited and this has resulted in the availability of surplus quantity of WCO. Large portions of WCO are illegally dumped into rivers and wastelands causing environmental pollution [2, 5]. The use of WCO as a fuel for diesel engines would reduce human or animal consumption, the illegal dumping and environmental degradation. Biodiesel can be processed from different mechanisms; transesterification is the most common process, in this process an ester compound is replaced with an alcohol in the alkyl group [5, 6, 7]. Biodiesel can be defined as fatty acid methyl esters (FAME) derived from the transesterification of triglycerides (vegetable oils or animal fats) with alcohol and suitable catalyst $[6,8,9,10]$. Biodiesel is used as mix constituent of petroleum diesel in proportions for running a diesel engine, since using neat biodiesel has some engine issues [7, 11]. The crops identified for biodiesel are corn, sunflower, palm, olive, canola, soybean, rape and peanut soils, and animalbased lipid [8]. Economic feasibility of biodiesel depends on the availability of low-cost feed stocks [12]. The key issue for large scale application of biodiesel compared to petroleum diesel is the high cost of biodiesel due to the high cost of feedstock oils as both the edible and non-edible oils are limited. Moreover, it has been reported that nearly $70-95 \%$ of the total production cost is related to the cost of raw materials. This issue can be overcome by the use of waste cooking oil (WCO) as raw material which can effectively reduce the feedstock cost to $60-70 \%$. Likewise, the cost of catalyst also affects the overall production cost. Several studies have been made to use waste materials for low cost catalyst preparation to develop sustainable biodiesel production process $[13,9]$. This paper studies the physical and chemical properties of waste cooking oil, transesterification and production of biodiesel from waste cooking oil. The factors affecting the process parameters reported are studied and the point of interest focuses on their alcohol to oil ratio, reaction temperature, catalyst both qualitative and quantitative scope and the optimum condition.

\section{Experiments}

\subsection{Materials}

The waste cooking oil three samples have been collected from three different units and have been named as sample I, II \& III. Sample I was taken after being used once for big restaurants, Sample II was collected from the Yarmouk University campus cafeteria and was taken after being used mostly twice, and sample III was collected from small shops in Irbed city, Jordan, which is mostly the kind of used cooking oil produced after repeated cooking or deepfrying several time. The WCO with 5-10 1 each, was filtered to remove bits of food particles, and heated to about $110^{\circ} \mathrm{C}$ for $10-15$ minutes to remove any traces of water. The free fatty acid (FFA) value of the used oil was tested and found to be less than $2 \%$; therefore, a one-step transesterification process was used for biodiesel production from the samples of used cooking oils. The characteristics of the WCO samples are illustrated in Tables 1 and 2. Acid values of the samples varied from 0.67 to $1.43 \mathrm{mg} \mathrm{KOH} / \mathrm{g}$. The acid value was relatively low in sample I, which was used once. The low level of free fatty acid content in the WCO samples could be an advantageous for an alkali catalyzed trans-esterification process. The samples had saponification values ranging from 252 to 270 $\mathrm{mg} \mathrm{KOH} / \mathrm{g}$ oil. Considering the composition of the samples, the WCO molecular weights can be calculated to be between 678.1 and $704.3 \mathrm{~g} / \mathrm{mol}$. This value was much lower than WCO found in other research, which had molecular weight ranging from 866 to $873.4 \mathrm{~g} / \mathrm{mol}[1,14,15]$. These WCO samples had 10 times higher viscosity than diesel oil. They are composed mainly of saturated short length fatty acid alkyl chains, which was $40-47 \mathrm{wt} \%$ of $\mathrm{C} 12: 0,16 \mathrm{wt} \%$ $\mathrm{C} 14: 0,10 \mathrm{wt} \% \mathrm{C} 16: 0$ and less than $10 \mathrm{wt} \%$ of unsaturated compounds (Table 2). The methanol used ( $99 \%$ pure) is of analytical grade with boiling point of $78^{\circ} \mathrm{C}$; the, $\mathrm{KOH}$ and anhydrous calcium chloride were of analytical grade and purchased from Loba Chemie Pvt. Ltd. Diesel was taken from commercial diesel (No. 2) with their characteristics listed in Table 1. The WCO samples were mixed together prior to the transesterification.

Table 1. Physical properties of WCO Samples \& Diesel.

\begin{tabular}{lllllll}
\hline Property & Unit & Sample I & Sample II & Sample III & Mixed sample & diesel \\
\hline Flash point & $\mathrm{oC}$ & 272 & 249 & 267 & 264 & 86 \\
Could point & $\mathrm{oC}$ & 26,00 & 18.50 & 20.00 & 20.4 & 0 \\
Density & $\mathrm{g} / \mathrm{cm}^{3}$ & 0.92 & 0.92 & 0.92 & 0.92 & 0.83 \\
Viscosity & $\mathrm{mm}^{2} / \mathrm{s}$ & 32.08 & 37.8 & 33.74 & 36.5 & 3.43 \\
Acid number & $\mathrm{mg} \mathrm{KOH} / \mathrm{g}$ & 0.76 & 1.13 & 1.63 & 1.43 & 0.13 \\
Saponification number & $\mathrm{mg} \mathrm{KOH} / \mathrm{g}$ & 252.24 & 270.32 & 268.68 & 260.16 & - \\
Iodine number & $\mathrm{mg} \mathrm{KOH} / \mathrm{g}$ & 9.84 & 8.78 & 12.02 & 10.67 & - \\
\hline
\end{tabular}


Table 2. Quantitative of fatty acids in WCO samples.

\begin{tabular}{lllll}
\hline Component & Sample 1 & Sample II & Sample III & Mixed sample \\
\hline C12:0 & 4222 & 46.23 & 44,37 & 43.21 \\
C14:0 & 16.64 & 17.26 & 16.31 & 16.84 \\
C16:0 & 8.88 & 7.26 & 10.58 & 9.82 \\
C16:1 & 0.00 & 0.01 & 0.22 & 0.12 \\
C18:0 & 2.54 & 2.02 & 1.82 & 2.20 \\
C18:1 & 6.02 & 4,36 & 8.04 & 5.96 \\
C18:2 & 1.35 & 1.41 & 1.68 & 1.51 \\
C18:3 & 0.00 & 0.00 & 0.02 & 0.00 \\
C20:0 & 0.00 & 0.11 & 0.04 & 0.02 \\
\hline
\end{tabular}

\subsection{Transesterification}

The transesterification was carried out in a $250 \mathrm{ml}$ threeneck glass flask equiped with a thermocouple and conneced with a reflux condenser using tap water to condense methanol vapor. The mixture was agitated by using a stainless steel stirrer. A $100 \mathrm{ml}$ sample of oil was introduced and heated to a temperature selected from $30^{\circ} \mathrm{C}, 40^{\circ} \mathrm{C}, 50^{\circ} \mathrm{C}$, $60^{\circ} \mathrm{C}$, and $70^{\circ} \mathrm{C}$. The amount of $\mathrm{KOH}$ catalyst used was ranging from $0.5 \mathrm{wt} \%$ to $2.0 \mathrm{wt} \%$ of the $\mathrm{WCO}$ and was dissolved into designed amount of methanol and poured into the flask. The transesterification reaction performed at different molar ratio of oil to methanol, varying from 1:4, $1: 5,1: 6,1: 7$ and 1:9. The mixture was maintained under stirring at the reaction temperature for designed period of time (30, 60, 90 and 120 minutes). At the completion of the reaction, the flask content was transferred to a separating funnel for glycerol and biodiesel separation for $12 \mathrm{~h}$. The lower darker layer containing glycerol has been removed. The upper layer containing biodiesel was washed several times with a small amount of hot water (to remove traces of glycerol), until the washing were neutral and dried on anhydrous calcium chloride $\left(\mathrm{CaCl}_{2}\right)$ to remove residual water. The percent yield of biodiesel was calculated using the following equation: Yield $\%=$ weight of produced biodiesel / weight of $\mathrm{WCO} * 100$

\subsection{Analysis}

Different physic-chemical propertied of WCO and biodiesel were measured by using ASTM standard methods, including density (D1298), kinematic viscosity at $40^{\circ} \mathrm{C}$ (D445), flash point (D93), cloud point (D2500), pour point (D97), cetane index (D976) and acid value (D664). The average molecular weight was calculated by $\mathrm{MW}=56.1 \times$ $1000 \times 3 /(\mathrm{SV}-\mathrm{AV})$, where AV $(\mathrm{mgKOH} /$ goil) and SV is the saponification value $(\mathrm{mgKOH} / \mathrm{goil})[16,17,18]$. Fatty acid quantitative was determined by using a Hitachi G-5000A GC (gas chromatography), analysis is performed for identifying the hydrocarbon compounds such as fatty acids and methyl esters. The separation is carried out by using capillary column Rtx-5MS $30 \mathrm{~m} \times 0.25 \mathrm{~mm}$ ID, $0.25 \mu \mathrm{m}$ with helium at $137.7 \mathrm{ml} / \mathrm{min}$ as a carrier gas and 1:100 of split ratio [19].

\section{Results and Discussion}

\subsection{Effect of Temperature}

Reaction temperature is the important factor that will affect the yield of biodiesel. For example, higher reaction temperature increases the reaction rate and shortened the reaction time due to the reduction in viscosity of oils. However, the increase in reaction temperature beyond the optimal level leads to decrease of biodiesel yield, because higher reaction temperature accelerates the saponification of triglycerides and causes methanol to vaporize resulting in decreasing the yield $[20,21,22]$. Usually the transesterification reaction temperature should be below the boiling point of alcohol in order to prevent the alcohol evaporation. Therefore, the reaction temperature near the boiling point of the alcohol is recommended for faster conversion by various literatures. Figure 1 shows the effect of temperature on the conversion at the methanol/oil ratio of $6: 1$ in the presence of $1 \mathrm{wt} \% \mathrm{KOH}$. For the same final reaction time, the percentage of esters increased with temperature. After $5 \mathrm{~min}$, the esters present in the 60, 50, and $30^{\circ} \mathrm{C}$ runs were $84.4,63.6$, and $51.3 \%$, respectively, showing the influence of temperature on ester conversion. At $90 \mathrm{~min}$, the percentages were 95.1, 80.6 and 70.5, respectively. Hence, there was an initial period during which the reaction was very fast, and then a second period, much longer than the first, in which the composition evolved slowly toward equilibrium. Therefore, the rate of reaction was strongly influenced by the reaction temperature. However, if the temperature increased up to $70^{\circ} \mathrm{C}$, there was a slight reduction in the conversion. This is because high temperature enhances both transesterification and saponification reactions $[24,23]$.

\subsection{Methanol to Oil Molar Ratio}

One of the most important parameters affecting the yield of biodiesel is the molar ratio of alcohol to triglyceride. Stoichiometrically 3 moles of alcohol and 1 mole of triglyceride are required for transesterification to yield 3 moles of fatty acid methyl/ethyl esters and 1 mole of glycerol is used. As can be observed in Figure 2, with a stoichiometric 
amount of methanol, the conversion to esters was near $70 \%$ after $1 \mathrm{~h}$. The ester yields increased as the percentage of methanol increased, with the best results being for a molar ratio of $6: 1$, and temperature of $60^{\circ} \mathrm{C}$ in the presence of 1 $\mathrm{wt} \% \mathrm{KOH}$. The conversion reached a value of above $50 \%$ in just $30 \mathrm{~min}$. increasing the ratio from $5: 1$ to $6: 1$ increased the conversion. It rose from $50 \%$ for the ratio of $5: 1$ to $66 \%$ for the ratio of $6: 1$. The difference in the conversion between the ratios of 5:1 and 6:1 was about $26 \%$ in the first 90 min and slightly decreased to $14-15 \%$ for the last $30 \mathrm{~min}$.

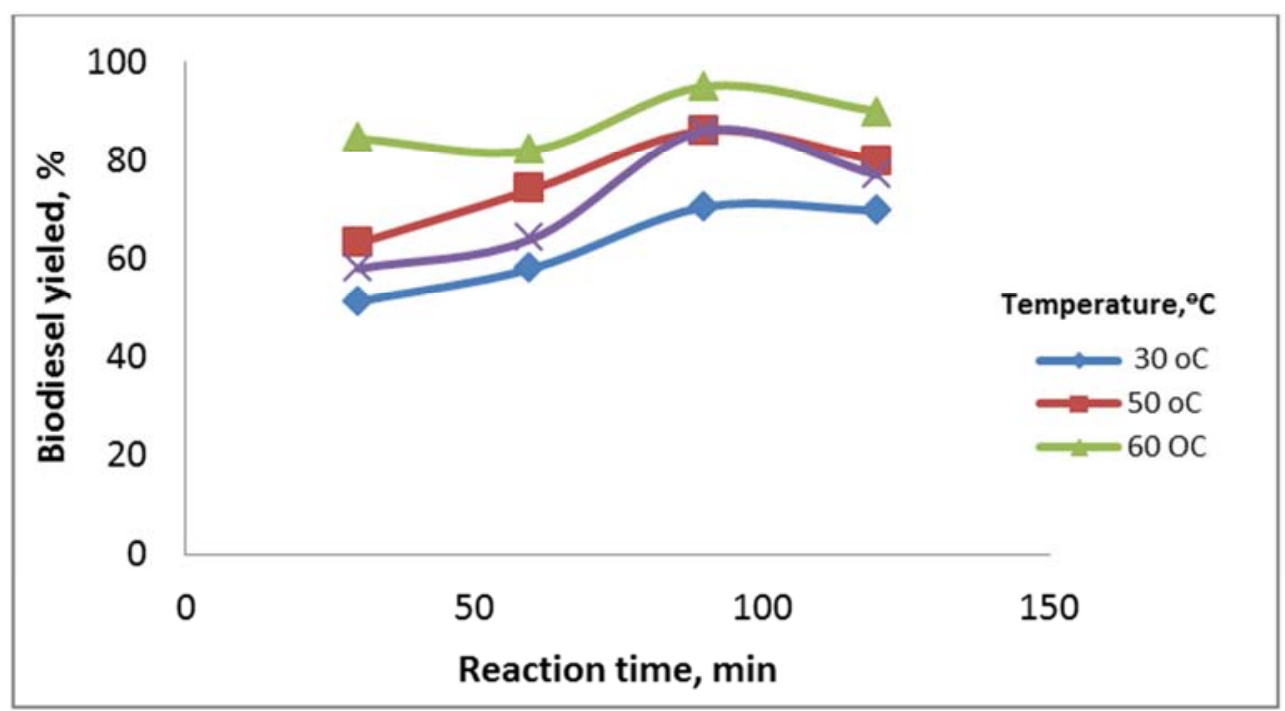

Figure 1. Effect of Temperature $60^{\circ} \mathrm{C}$ with reaction time (molar ratio 1:6 and $\mathrm{KOH} 1.0 \mathrm{wt} \%$ ).

The difference in the conversion was less than $5 \%$ when the methanol/WCO ratio increased from $6: 1$ to $7: 1$. A further increase in the methanol/WCO ratio above $7: 1$ caused a reduction in the conversion. It was $84 \%$ for the ratio of $9: 1$ compared to $88 \%$ for the ratio of $7: 1$ after $90 \mathrm{~min}$. For methanol/oil molar ratio less than $6: 1$ the reaction was incomplete, and at 9:1 methanol/oil molar ratio the separation of glycerol was difficult, since the excess methanol hindered the decantation by gravity so that the apparent yield of esters decreased because part of the glycerol remained in the biodiesel phase. Hence, the best results were obtained for an intermediate methanol/oil molar ratio of $6: 1$. These results are similar to those found in the literature [23, 25,].

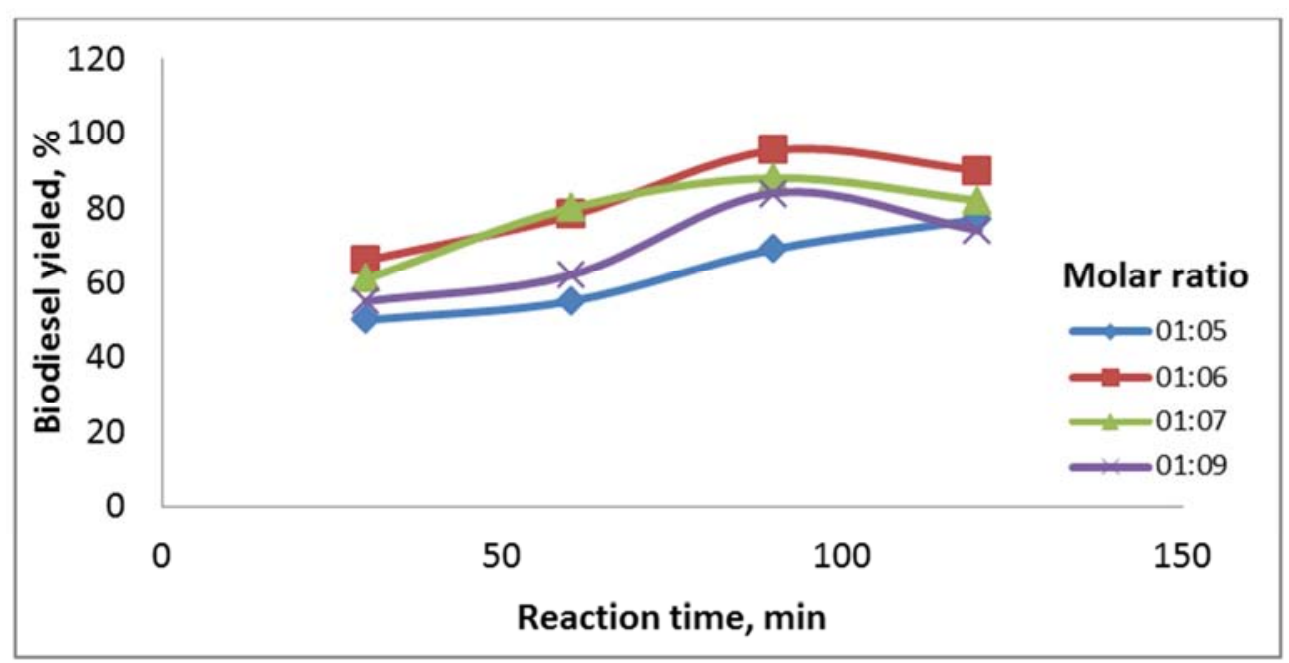

Figure 2. Effect of molar ratio with reaction time (Temperature $60^{\circ} \mathrm{C}$ and $\mathrm{KOH} 1.0 \mathrm{wt} \%$ ).

\subsection{Effect of Catalyst}

Fig 3, $\mathrm{KOH}$ is frequently soluble in solvent and easily promotes the reaction. Generally, catalyst concentration can affect the rate of biodiesel reaction and beyond the limitation of catalyst additions it's represented in Fig. 3. So, KOH catalyst used with $0.5,1.0,1.5$ and 2.0 wt. \% concentration for WCO, $0.5 \mathrm{wt} \%$ showed only $79.2 \%$ biodiesel yield and also 1.5 wt. $\%$ showed only $86 \%$ biodiesel yield. For $2.0 \mathrm{wt} \%$ catalyst showed biodiesel yield of $78.3 \%$ the decreases is due to the higher concentration of catalyst addition which gives a negative effect on the biodiesel production. On the other hand, using 1.0 wt. \% of catalyst showed $95.4 \%$ biodiesel yield for WCO which is higher biodiesel yield than the other 
concentrations. In general, as the catalyst concentration increased, the conversion of triglycerides also increased during $90 \mathrm{~min}$ time period. The conversion did not vary significantly above 90 min time period and slightly reduced in the last $30 \mathrm{~min}$. This could be explained by the fact that the formation of soap hindered the separation of the methyl ester phase during the washing step. The soap particles formed emulsions with water, which resulted in an increase in the viscosity. This phenomenon did not occur at low $\mathrm{KOH}$ concentrations. As a consequence, the yields of biodiesel were low for the cases of $1.5 \mathrm{wt} \%$ and $2 \mathrm{wt} \% \mathrm{KOH}$. This is because the addition of excess alkaline catalysts caused more triglycerides participation in the saponification reaction, resulting in increased production of soap and mentioned and a reduction of the esters yield $[1,23,26]$.

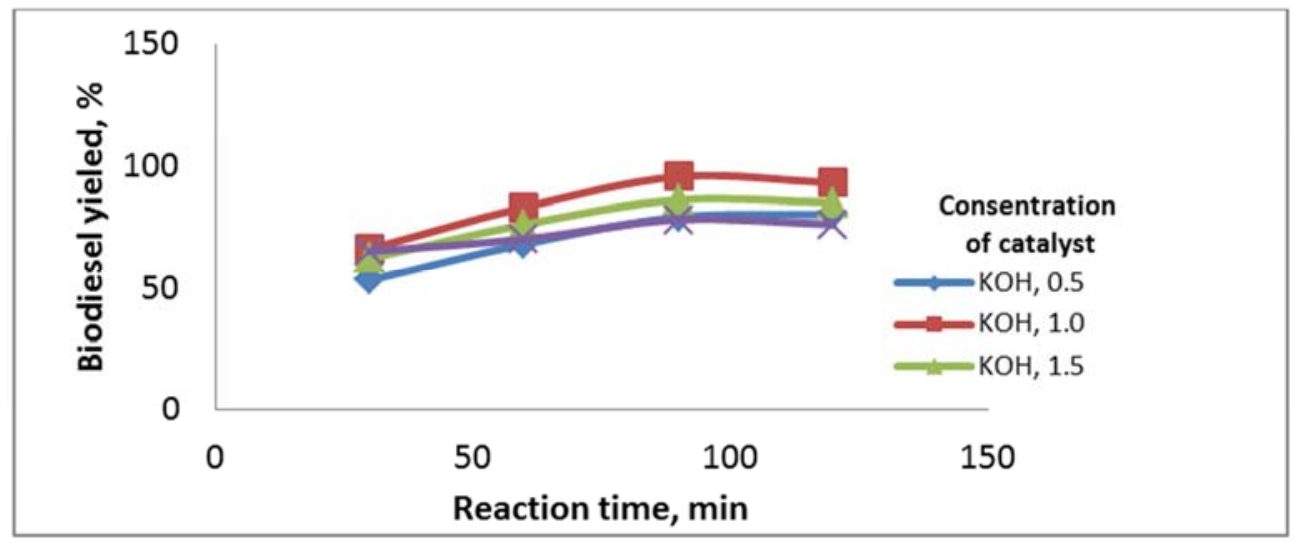

Figure 3. Effect of concentration of catalyst ( $\mathrm{KOH}$ ) with reaction time (Temperature $60^{\circ} \mathrm{C}$ and molar ratio 1:6).

\subsection{Effect of Reaction Time}

The increase in fatty acid esters conversion was observed when there was an increase in the reaction time. The reaction was slow at the beginning due to mixing and dispersion of alcohol and oil. after that the reaction proceeded very fast. According to many researchers, the biodiesel yields are directly proportional to the reaction times used. This experiment was conducted at reaction time of 30,60, 90 and 120 min with the constant parameters: $60^{\circ} \mathrm{C}$ of reaction temperature and $1 \mathrm{wt} \%$ of $\mathrm{KOH}$ catalyst used in $6: 1$ molar ratio of WCO. Figure 4 shows that effect longer mixing gives higher yield than using shorter time. So biodiesel yields increases with increasing the reaction time. However, based on the results, it shows 90 min reaction time gave a better result than other reaction times used here. In other words, $1 \mathrm{t}$ shows that the biodiesel yields were lower when reaction time of 120 min was used. This undesirable result may be due to the higher soap formation when longer reaction time was used. Thus, the rate of soap formation was also increased $[22,27]$.

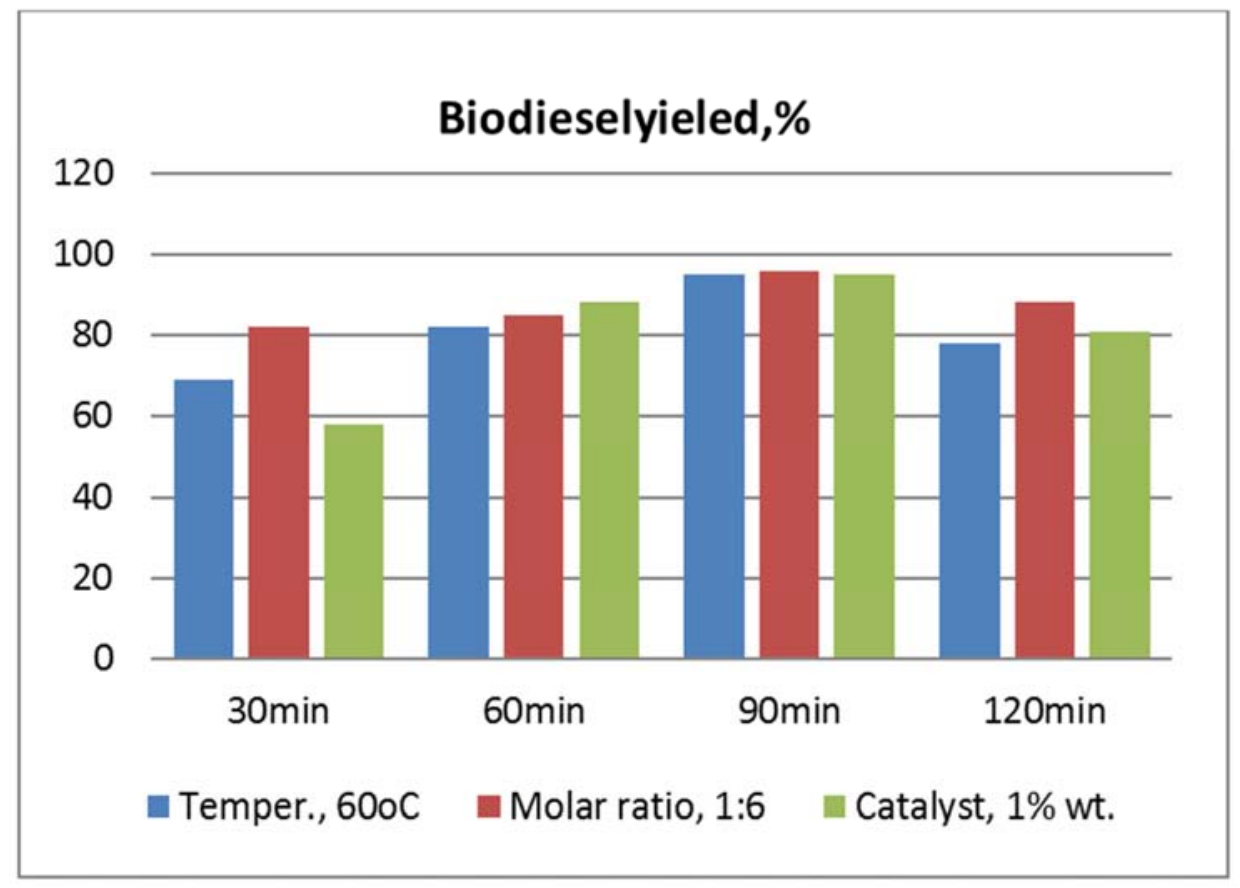

Figure 4. Effect of reaction time on production of Biodiesel yield (Concentration of catalyst (KOH) 1\%wt., Temperature 60 ${ }^{\circ} \mathrm{C}$ and molar ratio 1:6). 
Table 3. Characteristics of produced biodiesels in contrast with standard value.

\begin{tabular}{|c|c|c|c|c|c|}
\hline Property & Unit & Standard method (ASTM) & Value according standard method & Biodiesel (WCO) & Diesel \\
\hline Viscosity & $\mathrm{mm}^{2} / \mathrm{s}$ & D6751 & $1.9-6.0$ & 7.8 & 3.43 \\
\hline Acid number & $\mathrm{Mg} \mathrm{KOH/g}$ oil & D664 & $0.8 \max$ & 0.42 & 0.13 \\
\hline Density $\left(15^{\circ} \mathrm{C}\right)$ & $\mathrm{g} / \mathrm{cm}^{3}$ & D1298 & $0.86-0.90$ & 0.86 & 0.83 \\
\hline Flash point & ${ }^{\circ} \mathrm{C}$ & D 93 & $130(\min )$ & 135 & 86 \\
\hline Cloud point & ${ }^{\circ} \mathrm{C}$ & D2500 & - & 5 & 3 \\
\hline Pour point & ${ }^{\circ} \mathrm{C}$ & D97 & - & 1 & -7 \\
\hline Cetane index & - & D 976 & $47(\min )$ & 49 & - \\
\hline
\end{tabular}

\subsection{Characterization of Biodiesel}

Different physical properties of biodiesel including the kinematic viscosity, the density, the acid value, the flash point, the cloud point and the pour point, were measured to ensure they meet the international standards (ASTM D6751). Table 3 lists the results and also compares them with those of petroleum diesel fuel. It can be seen from this table that the biodiesel produced in this research has the required properties to be used in diesel engines. Chemical conversion of WCO into biodiesel resulted in significant reduction of the viscosity from $36.5 \mathrm{~mm}^{2} / \mathrm{s}$ for WCO to $7.8 \mathrm{~mm}^{2} / \mathrm{s}$ for biodiesel. This fact shows that biodiesel viscosity is well consistent with the required value in ASTM standard. Therefore, by transesterification, engine problems associated with high viscosity of waste cooking oils such as incomplete combustion and ignition delay will be eliminated [24, 25]. The density of biodiesel, which influences the quality of atomization process, and the acid value of biodiesel, which is a measure of free fatty acid content, also matched ASTM standards, as shown in table 3 . The flash point $\left(135^{\circ} \mathrm{C}\right)$ was much higher than that of diesel $\left(86^{\circ} \mathrm{C}\right)$, and hence, shows that there is no alcohol residue in biodiesel structure. Consequently, transportation, storage and handling of this biodiesel are better than the conventional diesel in terms of safety. The cloud point and pour point are greater than those obtained by other researchers [18,27], making this biodiesel less suitable for performance in cold conditions if used in pure form. However, biodiesel is frequently blended at different ratios with petroleum diesel to overcome these problems of the pure form.

\section{Conclusion}

Used frying oil has suitable characteristics for transesterification. The process produced biodiesel with properties similar to those of diesel. Consequently, the use of waste frying oil is an effective way to reduce the raw material cost. Besides, the pollution problems were reduced. The optimum conditions for biodiesel production from WSCO have been studied. Result shows optimal condition of biodiesel productions are 1:6 volumetric oil-to-methanol molar ratio, $1 \mathrm{wt} . \% \mathrm{KOH}$ at $60^{\circ} \mathrm{C}$ reaction temperature. This study has provided evidence that waste cooking oil may be employed as a substantial source of biodiesel as fuel in diesel engines. Because, the produced biodiesel is of good quality within the array of standard method specifications and the production yield is apt. up to approximately $99 \%$ under optimum conditions. Biodiesel from used cooking oil could be used as a diesel fuel which considered as renewable energy and environmental recycling process from waste oil after frying. Nevertheless, the transesterification progressed satisfactorily even at room temperature, which could be very interesting for industrial-scale production due to the energy savings that it would imply.

\section{References}

[1] Anh N. Phan, Tan M. Phan, Biodiesel production from waste cooking oils, Fuel vol. 87, 2008, pp. 3490-3496.

[2] Jose M. Encinar, et al., Biodiesel from Used Frying Oil. Variables Affecting the Yields and Characteristics of the Biodiesel, Ind. Eng. Chem. Res. Vol. 44, 2005, pp. 5491-5499.

[3] Srivastava A., Prasad R., Triglycerides-based diesel fuels. Renewable Sustainable Energy Re. vol. 4, 2000, pp. 111.

[4] Utlu Z., Evaluation of Biodiesel Fuel Obtained from Waste Cooking Oil, Energy Sources, Part A: Recovery, Utilization, and Environmental Effects vol. 29, No14, 2007, pp. 12951304.

[5] Mohammed Abdul Raqeeb and Bhargavi R., Biodiesel production from waste cooking oil, Journal of Chemical and Pharmaceutical Research, vol. 7, No. 12, 2015, pp. 670-681.

[6] A. Javidialesaadi. S. Raeissi, Biodiesel Production from High Free Fatty Acid-Content Oils: Experimental Investigation of the Pretreatment Step; APCBEEP rocedia vol. 5, 2013, pp. 474-478.

[7] Shirley J. et al., Effect of Temperature and Particle Size on the Yield of Bio-oil, Produced from Conventional Coconut Core Pyrolysis, International Journal of Chemical Engineering and Applications vol. o7, No2, 2016, pp. 102-108.

[8] María Jesús Ramos, et al., Influence of fatty acid composition of raw materials on biodiesel properties Bioresource Technology, vol. 100, 2009, pp. 261-268.

[9] Huseyin Sanli, Mustafa Canakci, Ertan Alptekin, Characterization of Waste Frying Oils Obtained from Different Facilities. World renobyl energy, Sweden, 8-13 mart., 2011.

[10] F. Jalala, S. Paneer selvamband, L. R. Miranda, Fatty methyl ester from vegetable oils for use as adiesel fuel International Journal of Renewable Energy Resources vol. 1, 2011, pp. 3236.

[11] Zaibunnisa Hussain, Saeed Ahmad Nagra, Mehwish Jamil, Production of Biodiesel from Waste Canola Cooking Oil in Pakistan, International Journal of Chemical Engineering and Applications vol. 6, No 6, 2015, pp. 55-61. 
[12] Murchana Pathak1, et al. (2015). Production of Biodiesel from Waste Cooking Oil vol. 5, No 5, 2015, pp. 60-64.

[13] R. B. Sharma, Dr. Amit P. J. Sharaf, Production of bio-diesel from waste cooking oil Int. Journal of Engineering Research and Applications vol. 3, No 6, 2013, pp. 1629-1636.

[14] Cetinkaya M, Karaosmanoglu F., Optimisation of basecatalysed transesterification reaction of used cooking oil, Energy Fuels vol. 18, 2004, pp. 1888-95.

[15] Encinar JM, Gonzalez JF, Rodriguez-Reinares A., Biodiesel from used frying oil: Variables affecting the yields and characteristics of the biodiesel. Ind Eng Chem Res. Vol. 4, 2005, pp. 5491-9.

[16] George A, Ypatia Z, Stamoulis S. and Stamatis K., Transesterification of vegetable oil with ethanol and characterization of the key fuel properties of ethyl esters. Energies vol. 2, 2009, pp. 362-376.

[17] Zhu H, et al., Preparation of biodiesel catalyzed by solid super base of calcium oxide and its refining process. Chin. J. Catal. vol. 27, 2006, pp. 391-396.

[18] Hiba Abdalla Mahgoub, et al. Suitable Condition of Biodiesel Production from Waste Cooking Oil-Al-Baha City - KSA, International Journal of Multidisciplinary and Current Research, ISSN: 2321-3124 Available at: http://ijmcr.com.

[19] Azhari Muhammad Syam, et al., Waste Frying Oils-Based Biodiesel: Process and Fuel Properties, Smart Grid and Renewable Energy vol. 4, 2013, pp. 281-286.

[20] Mathiyazhagan M, Ganapathi A, Factors Affecting Biodiesel Production, Research in Plant Biology: Review, Article vol. 1, No (2), 2011, pp. 01-05.
[21] Anitha A., Dawn S., Performance Characteristics of Biodiesel Produced from Waste Groundnut Oil using Supported Heteropolyacids. International Journal of Chemical Engineering and Applications vol. 1, No (3), 2010, pp. 261265.

[22] Alemayehu Gashaw1, Abile Teshita, Production of biodiesel from waste cooking oil and factors affecting its formation: A Review, International Journal of Renewable and Sustainable Energy; vol. 3, No (5), 2014, pp: 92-98.

[23] K. Dhanasekaran, M. Dharmendirakumar, Optimization study of biodiesel used frying oil Int. J. Curr. Microbiol. App. Sci. vol. 3, No (2), 2014, pp: 727-7351.

[24] Tahereh Hajy Heidar, 1and Kambiz Tahvildari, Efficient Synthesis of Biodiesel From Waste Cooking Oil Catalysed by Al2O3 Impregnated with $\mathrm{NaOH}$, Journal of Chemical and Petroleum Engineering vol. 49, No (2), 2015, pp. 143-151.

[25] A. Hossain, A. Boyce, Biodiesel production from waste sunflower cooking oil as environmental recycling process and renewable energy. Bulgarian Journal of Agricultural Science vol. 15, No (4), 2009, pp. 312-317.

[26] Lakshmana Naik $R$, et al. Optimized Parameters for Production of Biodiesel from Fried Oil. International Advanced Research Journal in Science, Engineering and Technology vol. 2, No 6, 2015, pp. 23.

[27] Zlatica J. Predojevic, The production of biodiesel from waste frying oils: A comparison of different purification steps, Fuel vol. 87,2008 , pp. 3522-3528. 